\title{
Ultracytochemical Localization of ATP-hydrolysing Activity in Vegetative Cells, Spores and Isolated Cytoplasmic Membranes of Bacillus subtilis 168
}

\author{
By NADJA V. CHEREPOVA, * SVETLA P. BAYKOUSHEVA AND \\ KONSTANTINA Z. ILIEVA \\ Institute of Microbiology, Bulgarian Academy of Sciences, 1113 Sofia, Bulgaria
}

(Received 25 July 1985 ; revised 7 October 1985)

The localization of ATP-hydrolysing activity in vegetative cells, spores and isolated membranes of Bacillus subtilis 168 was studied by a cytochemical method combined with electron microscopy. The activity was located mainly in the cytoplasmic membrane and the mesosomes, and was also found in the inner layer of the cell wall facing the cytoplasmic membrane. Activity was also detected in the cross-membranes of dividing cells and in spore coats. The product of the reaction was observed either as fine electron-dense granules incorporated into the membranes, or as high-contrast lead precipitates on the surfaces of the membranes.

\section{INTRODUCTION}

The ATP synthases of prokaryotes resemble in structure and function the protontranslocating ATPases of higher organisms (Monteil \& Serrahima-Zieger, 1978; Downie et al., 1979; Munoz, 1982; Sigler, 1982; Senior \& Wise, 1983). They consist of a hydrophobic membrane-integrated part $\left(\mathrm{F}_{0}\right)$ and a membrane-associated part $\left(\mathrm{F}_{1}\right)$ which exhibits ATPhydrolysing activity (Futai \& Kanazawa, 1983; Schneider \& Altendorf, 1984). The protontranslocating $\mathrm{BF}_{0} \cdot \mathrm{BF}_{1}$ complex has both ATPase and ATP synthase activity, but it will be referred to as the ATPase throughout this paper.

Almost all efforts to establish the precise location and distribution of ATPases in bacteria have been based on subcellular fractionation and subsequent biochemical studies of the isolated components (Salton, 1974, 1976; Serrahima-Zieger \& Monteil, 1978, 1982). Such studies have shown the enzyme to be localized in the cytoplasmic membrane and not present in mesosomes (Salton, 1976). Electron-microscopic observations of cells using negative-staining techniques have been of little value in elucidating the localization of particular proteins or in determining the specific molecular architecture of the bacterial cell.

Cytochemical methods combined with electron microscopy have been used to study the localization of ATPase in whole cells and in isolated membranes of several bacterial species (Voelz, 1964; Kushnarev et al., 1968; Wetzel et al., 1970; Mikhaleva et al., 1984). Oppenheim \& Salton (1973) established the asymmetric disposition of the enzyme and 'mapped' its sites on the cytoplasmic membrane of Micrococcus lysodeikticus by means of ferritin-labelled antibody. Since no significant labelling occurred when ferritin conjugate was reacted with intact protoplasts or mesosome fractions, they concluded that the ATPase was localized on the inner surface of the cytoplasmic membrane. Our preliminary results showed that ATP-hydrolysing activity was present in mesosomes of Bacillus subtilis (Cherepova et al., 1984). The present study was undertaken to elucidate the distribution of the ATPase in whole cells, spores and isolated membranes of $B$. subtilis.

Abbreviation: DCCD, $N, N^{\prime}$-dicyclohexylcarbodiimide. 


\section{METHODS}

Bacterium. B. subtilis strain 168 was used.

Medium and growth conditions. All experiments were done in a liquid culture medium containing $\left(\mathrm{g}^{-1}\right)$ : peptone (Difco), 10 ; yeast extract (Difco), $10 ; \mathrm{NaCl}, 5 ; \mathrm{Na}_{2} \mathrm{PO}_{4}, 0 \cdot 4 ;$ the $\mathrm{pH}$ was adjusted to $7 \cdot 2$.

Cultures were incubated for 12 or $24 \mathrm{~h}$ at $37^{\circ} \mathrm{C}$ with vigorous shaking. Cells were harvested by centrifugation and washed three times in $0.05 \mathrm{M}$-Tris/ $\mathrm{HCl}$ buffer, $\mathrm{pH} 7.5$.

Isolation of membranes. Cells grown for $12 \mathrm{~h}$ were subjected to the treatment described by Konings et al. (1973) to obtain membranes.

Cytochemical methods. The pellets obtained after centrifugation of cells, spores or isolated cytoplasmic membranes were washed in $0.2 \mathrm{M}$-Tris/maleate buffer, $\mathrm{pH} 7.2$ (buffer $\mathrm{A}$ ), centrifuged and fixed in $6.25 \%(\mathrm{w} / \mathrm{v})$ glutaraldehyde in $0.1 \mathrm{M}$-cacodylate buffer, $\mathrm{pH} 7 \cdot 2$, at $4{ }^{\circ} \mathrm{C}$ for $2 \mathrm{~h}$. The suspension was centrifuged and washed in buffer $\mathrm{A}$ at $4{ }^{\circ} \mathrm{C}$ for $20 \mathrm{~min}$. The pellet was resuspended in an incubation mixture containing: ATP disodium salt (Koch Light) $20 \mathrm{ml}\left(0.83 \mathrm{~mm}\right.$ final concn); buffer $\mathrm{A}, 20 \mathrm{ml}$; solution of $\mathrm{Pb}\left(\mathrm{NO}_{3}\right)_{2}(2 \%, \mathrm{w} / \mathrm{v}), 3 \mathrm{ml} ; 0.1 \mathrm{M}-\mathrm{CaCl}_{2}$, $5 \mathrm{ml}$; double-distilled water, $2 \mathrm{ml}$. The solution of $\mathrm{Pb}\left(\mathrm{NO}_{3}\right)_{2}$ was added slowly drop-wise to the mixture with constant stirring, and the incubation medium was filtered and brought to $\mathrm{pH} 7.2$. In control experiments the incubation mixture either lacked the substrate for the reaction (ATP), or contained a specific inhibitor of ATPase, $N, N^{\prime}$-dicyclohexylcarbodiimide (DCCD) (Fluka) at a concentration of $10^{-4} \mathrm{M}$. After incubation of the sampies for $30 \mathrm{~min}$ at $37^{\circ} \mathrm{C}$, the suspension was centrifuged and washed twice in buffer $\mathrm{A}$ and processed for electron microscopy. The cytochemical methods used were based on those of Wachstein \& Besen (1963), adapted by us for bacterial cells.

Electron microscopy. The samples were fixed overnight by the method of Kellenberger et al. (1958) or that of Sabatini et al. (1963), then dehydrated in increasing concentrations of alcohol and embedded in Durcopan. Staining was done by the method of Reynolds (1963). Thin sections were examined with an Opton CM electron microscope.

\section{RESULTS AND DISCUSSION}

The localization of the ATPase in B. subtilis 168 was studied in thin sections of whole vegetative cells, spores and isolated membranes.

Localization in vegetative cells. Fig. $1(a-d)$ shows ultrathin sections of intact cells of $B$. subtilis 168 grown for $12 \mathrm{~h}$ and stained specifically to demonstrate the presence of the ATPase. The product of the reaction (lead phosphate) was seen mainly in the cytoplasmic membrane, the mesosomes and in some cases on the inner layer of the cell wall facing the cytoplasmic membrane as well as in the cross-membranes of dividing cells. The staining due to lead phosphate formation was very dense and in some cases large dark granules were observed on the surface of membrane structures. Control cells incubated without ATP or in the presence of DCCD are shown in Fig. 2.

Localization in spores. After $24 \mathrm{~h}$ cultivation most of the cells were converted into spores. There was considerable accumulation of lead phosphate in the spore coats, making them very electron-dense (Fig. $3 a, b$ ). In the control experiment, in which spores were incubated in the absence of ATP, there was much less accumulation of lead phosphate in the spore coats (Fig. 3c).

Localization in isolated membranes. The cytochemical reaction was particularly pronounced in isolated membranes of $B$. subtilis, permitting a more precise differentiation of the types of deposition of the reaction product (Fig. $4 a-c$ ). Small, fine dark granules were incorporated in the osmiophilic layers of the membranes, which contributed to the higher contrast and electron density. Large dense granules were also observed on the surface of membrane structures. Similar results were obtained by Goldfischer et al. (1964) with respect to the visualization of ATPase in mitochondrial membranes.

As pointed out by Voelz (1964) the ATPase reaction in this cytochemical method is specific. Nevertheless, in order to exclude any possibility of non-specific formation of lead phosphate we used two controls, either omitting ATP from the incubation mixture or adding the specific ATPase inhibitor DCCD, which binds to the $\mathrm{F}_{0}$ part of the synthase, blocking $\mathrm{H}^{+}$conduction and thus inhibiting both the synthesis and the hydrolysis of ATP (Downie et al., 1979; 

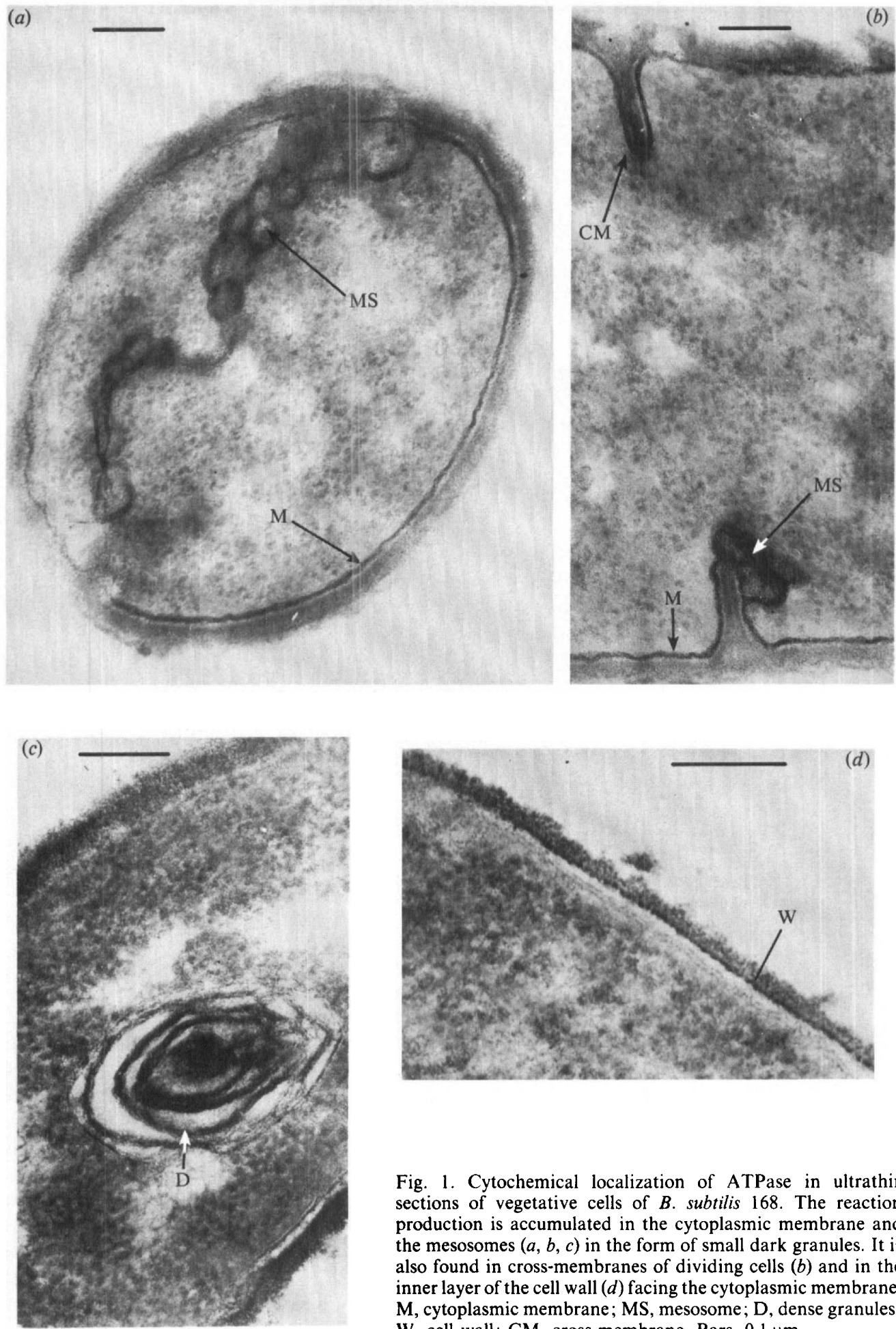

Fig. 1. Cytochemical localization of ATPase in ultrathin sections of vegetative cells of $B$. subtilis 168 . The reaction production is accumulated in the cytoplasmic membrane and the mesosomes $(a, b, c)$ in the form of small dark granules. It is also found in cross-membranes of dividing cells $(b)$ and in the inner layer of the cell wall $(d)$ facing the cytoplasmic membrane. $\mathrm{M}$, cytoplasmic membrane; MS, mesosome; D, dense granules; $\mathrm{W}$, cell wall; CM, cross-membrane. Bars, $0 \cdot 1 \mu \mathrm{m}$. 

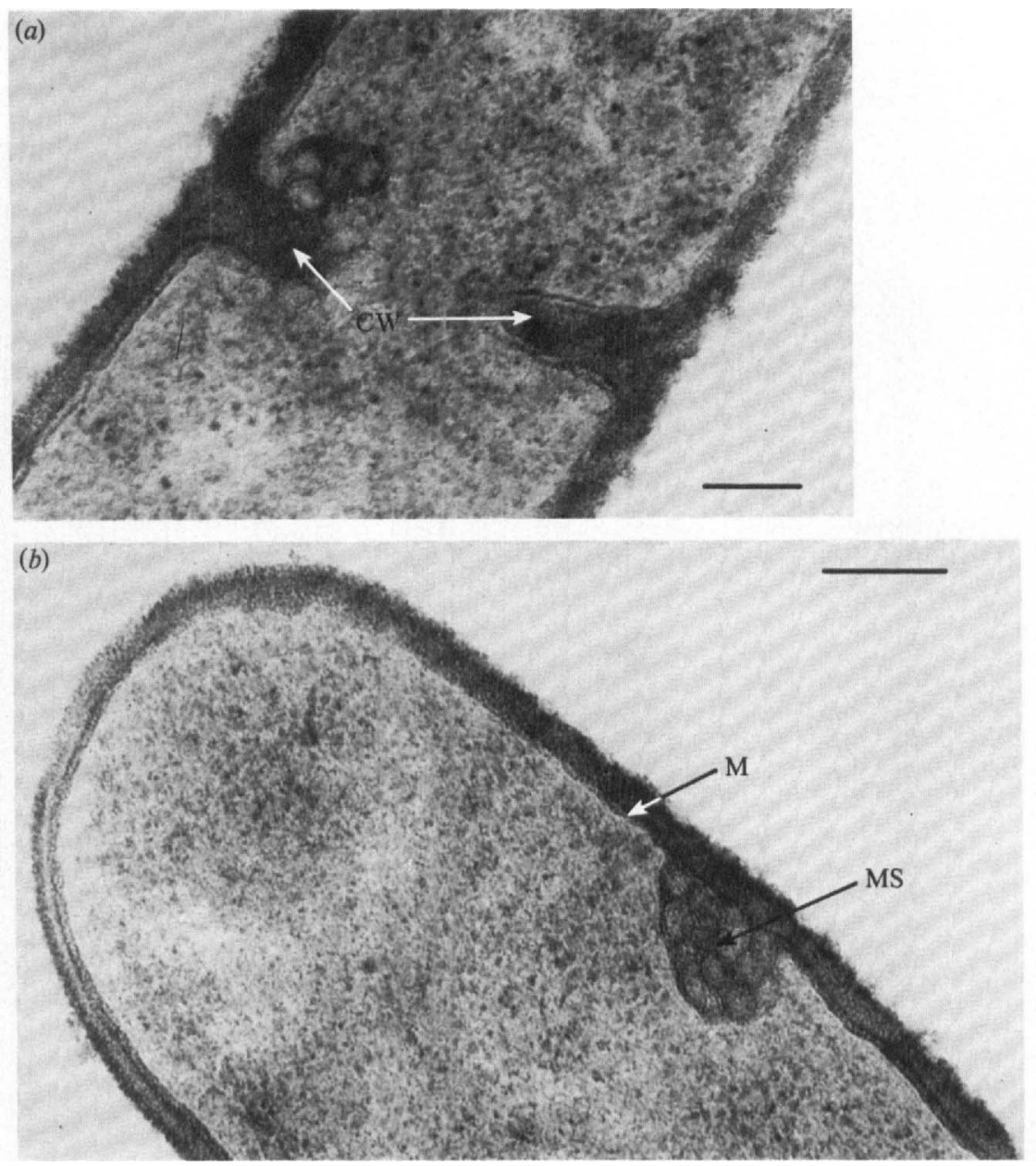

Fig. 2. Ultrathin sections of vegetative cells of $B$. subtilis 168 incubated in the absence of ATP $(a)$ or in the presence of $\operatorname{DCCD}(b)$. CW, cross-wall; M, cytoplasmic membrane; MS, mesosome. Bars, $0 \cdot 1 \mu \mathrm{m}$.

Serrahima-Zieger \& Monteil, 1982). In both controls the dense lead phosphate deposits characteristic of the ATPase cytochemical reaction were not observed (Figs 2, 3c, 4d). The two different fixation techniques (with or without preliminary fixation of the samples) that were used gave similar results.

Variable localization of ATPases in different microbial species was established by Voelz (1964). In Escherichia coli the enzyme was found mainly in the cytoplasmic membrane and the cell wall, in Bacillus cereus it was observed in the cytoplasmic membrane, the cytoplasm and the nuclear region of the cell, while in Myxococcus xanthus it was seen only in the cytoplasm. The author supposed that these variations could be due to differences in the physiological state (phase of growth) of the micro-organisms. Mikhaleva et al. (1984) demonstrated ATPase in isolated membrane vesicles from $E$. coli by using a combination of cytochemistry and electron microscopy, and Kubak \& Jotis (1981) used negative staining and electron microscopy to prove the presence of ATPase in isolated membranes of Staphylococcus aureus. Kushnarev et al. (1968) studied the distribution of the enzyme in intact cells of $S$. aureus and showed that it was localized 

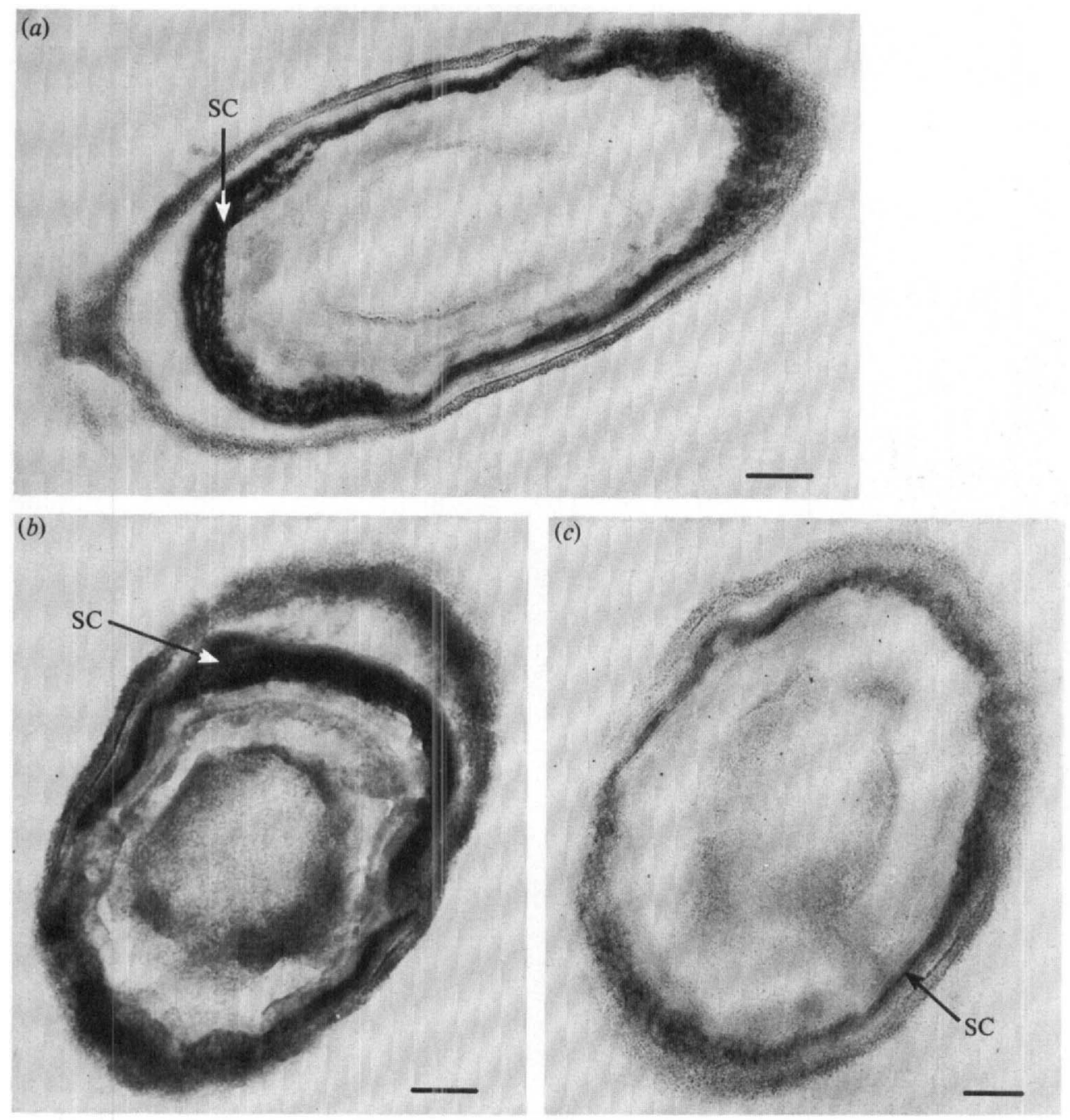

Fig. 3. Ultrathin sections of spores of $B$. subtilis $168 .(a, b)$ The product of the reaction is found in the spore coats and contributes to the higher contrast and electron density of the layers where it is localized. (c) After incubation in the absence of ATP the loci of ATPase reaction are of much lower contrast. SC, spore coats. Bars, $0 \cdot 1 \mu \mathrm{m}$.

in the cytoplasmic membrane, the mesosomes and the cross-walls of dividing cells. Studying isolated membranes of another Gram-positive micro-organism, Micrococcus lysodeikticus, Oppenheim \& Salton (1973) and Salton $(1974,1976)$ did not find ATPase in mesosomal fractions. Our results, and those of Kushnarev et al. (1968), who also used cytochemical methods to demonstrate the ATPase, show that the enzyme is present in both the mesosomes and the cytoplasmic membranes. This is not surprising if we take into account that mesosomes are thought to originate from the cytoplasmic membrane.

The ATPase of $B$. subtilis has been isolated from cytoplasmic membranes, purified and characterized by Serrahima-Zieger \& Monteil $(1978,1982)$. To our knowledge the present study is the first attempt to elucidate the localization of the enzyme in this micro-organism using a cytochemical method combined with electron microscopy. 

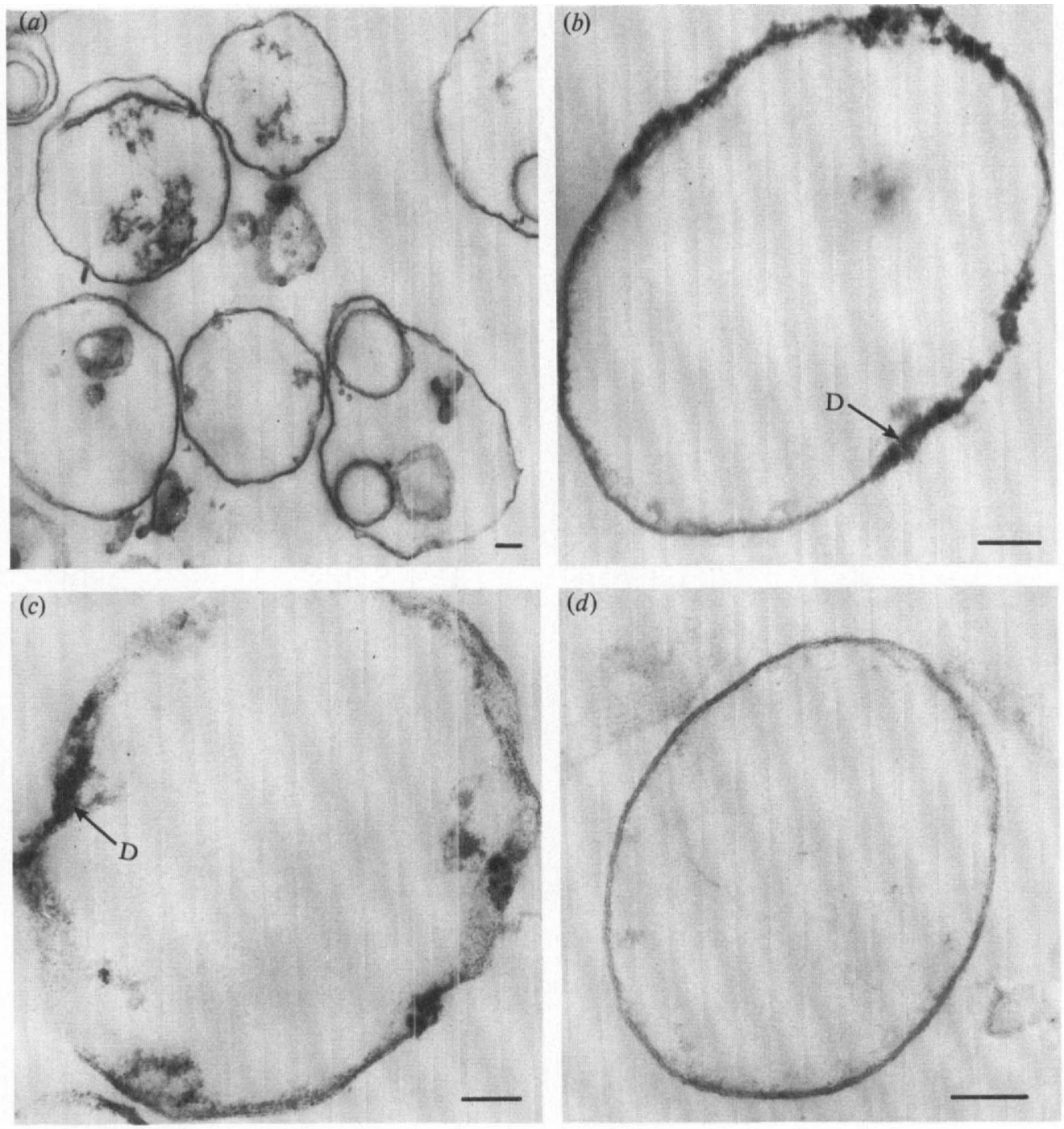

Fig. 4. Cytochemical localization of ATPase in isolated cytoplasmic membranes of B. subtilis 168 . The reaction product in the form of fine granules is incorporated into the membranes making them more electron-dense $(a)$. In some cases, besides incorporation of the product into the membranes, accumulation of large lead phosphate precipitates on the surface of the membranes is observed $(b, c)$. When isolated cytoplasmic membranes were incubated in the presence of DCCD neither incorporation nor accumulation of the reaction product was observed $(d)$. D, dense granules. Bars, $0.1 \mu \mathrm{m}$. 


\section{REFERENCES}

Cherepova, N. V., Baikousheva, S. P. \& Ilieva, K. Z (1984). Electron-microscopic demonstration of the localization of adenosine triphosphatase in Bacillus subtilis. Comptes rendus de l'Académie bulgare des Sciences 37, 641-643.

Downie, J. A., Gibson, F. \& Cox, G. B. (1979). Membrane adenosine triphosphatases of prokaryotic cells. Annual Review of Biochemistry 48, 103-131

FutaI, M. \& Kanazawa, H. (1983). Structure and function of proton-translocating adenosine triphosphatase $\left(F_{0} F_{1}\right)$ : biochemical and molecular biological approaches. Microbiological Reviews 47, 285312.

GoldFISCHER, S., ESSNER, E. \& NovikofF, A. B. (1964). The localization of phosphatase activities at the level of ultrastructure. Journal of Histochemistry and Cytochemistry 12, 72-95.

Kellenberger, E., Ryter, A. \& Sechaud, J. (1958). Electron microscope study of DNA-containing plasms. II. Vegetative and mature phage DNA as compared with normal bacterial nucleoids in different physiological states. Journal of Biophysical and Biochemical Cytology 4, 671-676.

Konings, W. N., BischoP, A., VeEnhuis, M. \& Vermedlen, C. A. (1973). New procedure for the isolation of membrane vesicles of Bacillus subtilis and an electron microscopy study of their ultrastructure. Journal of Bacteriology 116, 1456-1465.

KUBAK, B. M. \& Jotis, W. W. (1981). Staphylococcus aureus adenosine triphosphatase: inhibitor sensitivity and release from membrane. Journal of Bacteriology 146, 385-390.

Kushnarev, V. M., Bykov, A. S., Smirnova, T. A. \& TJURIN, V. S. (1968). An electron microscopy study of adenosine triphosphatase activity of Staphylococcus aureus. Mikrobiologiya 37, $100 \cdot 102$.

Mikhaleva, N. I., Gutevskaya, S. A., Nesmeyanova, M. A., Suzina, N. E. \& Fikhte, B. A. (1984). The effect of various cell disintegration procedures on the orientation of membranous vesicles in Escherichia coli. Mikrobiologiva 53, 432-436.

Monteil, H. \& Serrahima-Zieger, M. (1978). Les ATPases bactériennes: proprietés moléculaires et fonctions. Bulletin de l'Institut Pasteur 76, 207-246.

MUNoz, H. (1982). Polymorphism and conformational dynamics of $F_{1}$-ATPases from bacterial membranes. A model for the regulation of these enzymes on the basis of molecular plasticity. Biochimica et hiophysica acta 650, 233-265.
Oppenheim, J. D. \& Salton, M. R. J. (1973) Localization and distribution of Micrococcus lysodeikticus membrane ATPase determined by ferritin labeling. Biochimica et biophysica acta 298, 297-322.

REYNOLdS, E. S. (1963). The use of lead citrate at high $\mathrm{pH}$ as an electron-opaque stain in electron microscopy. Journal of Cell Biology 17, 208-212.

Sabatini, D. D., BensCh, K. \& BaRnetT, R. J. (1963). Cytochemistry and electron microscopy. The preservation of cellular ultrastructure and enzymatic activity by aldehyde fixation. Journal of Cell Biology 17, 19-58.

Salton, M. R. J. (1974). Membrane-associated enzymes in bacteria. Advances in Microbial Physiology 11, 213-282.

SAlton, M. R. J. (1976). Methods of isolation and characterization of bacterial membranes. In Methods in Membrane Biology, vol. 6, pp. 101-150. Edited by E. D. Korn. New York : Plenum Publishing Corp.

SCHNEIDER, E. \& AlTENDORF, K. (1984). The protontranslocating portion $\left(\mathrm{F}_{0}\right)$ of the Escherichia coli ATP synthase. Trends in Biochemical Sciences 9, 51-52.

SENIOR, A. E. \& WISE, J. G. (1983). The protonATPase of bacteria and mitochondria. Journal of Membrane Biology 73, 105-124.

Serrahima-Zieger, M. \& Monteil, H. (1978). Membrane ATPase of Bacillus subtilis. I. Purification and properties. Biochimica et biophysica acta 502, 445 457.

Serrahima-Zieger, M. \& Monteil, H. (1982). Isolation and purification of dicyclohexylcarbodiimidereactive proteolipid from Bacillus subtilis membrane. Biochimica et biophysica acta 679, 369-375.

Sigler, K. (1982). ATPases: common and unique features within a group of enzymes. Folia microbiologica 27, 195-210.

Voelz, H. (1964). Sites of adenosine triphosphatase activity in bacteria. Journal of Bacteriology 88, 1196 1198.

W ACHSTEIN, M. \& BeSEN, B. (1963). Electron microscopic localization of phosphatase activity in the brush border of the rat kidney. Journal of Histochemistry and Cytochemistry 11, 447-448.

Wetzel, B. K., SPICER, S. S., DVORAK, H. F. \& Heppel, J. A. (1970). Cytochemical localization of certain phosphatases in Escherichia coli. Journal of Bacteriology 104, 529-542. 